\title{
Stimulatory Effects of Nitric Oxide Donors on Histamine Release in Isolated Rat Gastric Mucosal Cells
}

\author{
Ko Hasebe, ${ }^{a, 1)}$ Syunji Horie, ${ }^{*}, a$ Shingo YAno, ${ }^{b}$ and Kazuo WatanABE ${ }^{a}$ \\ ${ }^{a}$ Laboratory of Chemical Pharmacology, Chiba University; and ${ }^{b}$ Laboratory of Molecular Pharmacology and \\ Pharmacotherapeutics, Graduate School of Pharmaceutical Sciences, Chiba University; Chiba 263-8522, Japan. \\ Received January 20, 2003; accepted April 2, 2003
}

\begin{abstract}
We previously reported stimulatory effects of endogenous and exogenous nitric oxide (NO) on gastric acid secretion. In the present study, we investigated effects of NO donors on release of histamine, which is related to

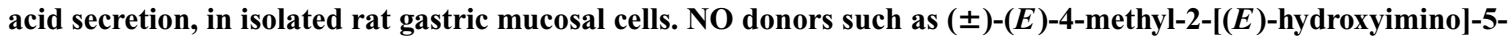
nitro-6-methoxy-3-hexanamide (NOR 1) and sodium nitroprusside significantly augmented the histamine release. It was inhibited by 2-(4-carboxyphenyl)-4,4,5,5,-tetramethylimidazoline-1-oxyl-3-amide (carboxy-PTIO), a NO scavenger, and 6-(phenylamino)-5,8-quinolinedione (LY83583), a soluble guanylate cyclase inhibitor. Dibutyryl cyclic GMP also stimulated histamine release. These results suggest that NO donors act on cyclic GMP pathway in isolated gastric mucosal cells, resulting in facilitation of histamine release. NO may stimulate gastric acid secretion through histamine release from the histamine-containing cells, possibly enterochromaffin-like cells.
\end{abstract}

Key words nitric oxide (NO); gastric acid secretion; histamine; cyclic GMP; enterochromaffin-like (ECL) cell; isolated rat gastric mucosal cell

Nitric oxide (NO) donors are known to inhibit gastric acid secretion in vivo and in vitro. ${ }^{2-4)}$ The inhibitory effect of endogenous NO on stimulated acid secretion has also been demonstrated in rats. ${ }^{5,6)}$ Thus, NO is generally thought to inhibit the stimulation of gastric acid secretion. On the contrary, we have demonstrated that NO has a stimulatory effect on gastric acid secretion: Sodium nitroprusside, a NO donor, increases acid secretion in isolated mouse stomach preparations. ${ }^{7)}$ Additionally, $N$-nitro-L-arginine, a NO synthase inhibitor, reduces gastric acid secretion induced by cholinergic agents and pentagastrin, suggesting the stimulation of acid secretion by endogenous $\mathrm{NO}^{8}$

In the gut, the cells that synthesize and release histamine are mucosal mast cells ${ }^{9)}$ and enterochromaffin-like (ECL) cells. ${ }^{10)}$ ECL cells are considered to be the origin of endogenous histamine, which is related to peripheral regulation of gastric acid secretion in rodents. ${ }^{11)}$ In our previous study, acid secretion induced by sodium nitroprusside and dibutyryl cyclic GMP, a cell-permeable analogue of cyclic GMP, was abolished by the histamine $\mathrm{H}_{2}$ receptor antagonist famotidine in isolated mouse stomach. ${ }^{7,12)}$ In addition, $N$-nitro-L-arginine inhibits bethanechol- and pentagastrin-induced histamine release in isolated rat gastric mucosal cell preparations. ${ }^{8)}$ These findings suggest that $\mathrm{NO}$ augments histamine release from the histamine-containing cells, resulting in the increased acid secretion. It is suggested that NO-cyclic GMP system in the histamine-containing cells are involved in enhancement of acid secretion, but whether NO donors induce an increase in histamine release has not yet been demonstrated. In the present study, we investigated the effects of NO donors on histamine release in isolated rat gastric mucosal cells.

\section{MATERIALS AND METHODS}

Determination of Histamine Release in Isolated Gastric Mucosal Cells Gastric mucosal cells were isolated from male Wistar rats weighing $280-360 \mathrm{~g}$ with a slight modification of the methods described by Schepp et al. ${ }^{13)}$ and Sakai et al. ${ }^{14)}$ Briefly, each rat was exsanguinated under ether anes- thesia, and the stomach was promptly removed. The pylorus was ligated, and the stomach was then turned inside out through the small hole made by $2-\mathrm{mm}$ incision in the forestomach. The everted stomach was filled with $5 \mathrm{ml}$ of solution A containing $0.1 \%$ pronase $\mathrm{E}$ and was incubated in two changes of solution $\mathrm{A}$ at $37^{\circ} \mathrm{C}$ for $45 \mathrm{~min}$ with gentle shaking under $95 \% \mathrm{O}_{2}-5 \% \mathrm{CO}_{2}$. The isolated cells were discarded, and then the everted stomach was incubated in solution B containing $0.2 \%$ pronase $\mathrm{E}$ at $37^{\circ} \mathrm{C}$ for $50 \mathrm{~min}$. Separated cells were collected, and resuspended in solution D. Then the stomach was stirred in three changes of ice-cold solution $\mathrm{B}$ for $10 \mathrm{~min}$ under $95 \% \mathrm{O}_{2}-5 \% \mathrm{CO}_{2}$. The cells separated were also collected in solution D. About $1 \times 10^{8}$ cells were obtained from 3 rats. Their viability was determined to be more than $95 \%$ by the trypan blue exclusion test (incubation with $0.04 \%$ trypan blue for $10 \mathrm{~min}$ ).

A Percoll density-gradient was formed by centrifuging (at $25000 \times \boldsymbol{g}$ for $50 \mathrm{~min}$ ) a mixture of Percoll, solution $\mathrm{C}$ and $1.5 \mathrm{M} \mathrm{NaCl}(45: 52: 3 \mathrm{v} / \mathrm{v})$. The isolated cells were laid on the Percoll gradient and centrifuged at $400 \times \boldsymbol{g}$ for $10 \mathrm{~min}$. The cells thus obtained were used for the experiment as the ECL cell-enriched fraction of gastric mucosal cells. Their viability was determined to be more than $95 \%$.

One-milliliter cell suspensions (containing about $5 \times 10^{5}$ cells) in microtubes were suspended in solution $\mathrm{D}$ for $45 \mathrm{~min}$ at $37^{\circ} \mathrm{C}$ in a shaking incubator after the addition of agents to be tested. The incubation was stopped after $45 \mathrm{~min}$ by centrifugation (at $4{ }^{\circ} \mathrm{C}, 400 \times \boldsymbol{g}$ for $5 \mathrm{~min}$ ). Histamine in the supernatant was measured using a radioimmunoassay kit (Immunotech, Marseilles, France).

We used four nutrient solutions, and their compositions were as follows: Solutions $\mathrm{A}$ and $\mathrm{C}$ contained (in $\mathrm{mM}$ ) $\mathrm{NaCl}$ $70, \mathrm{KCl} 5, \mathrm{NaH}_{2} \mathrm{PO}_{4} 0.5, \mathrm{Na}_{2} \mathrm{HPO}_{4} 1, \mathrm{NaHCO}_{3} 20$, glucose 11, ethylenediaminetetraethyl acetic acid (EDTA) 2 and HEPES-NaOH ( $\mathrm{pH} 7.4) 50 ; 20 \mathrm{mg} / \mathrm{ml}$ (solution A) or $1 \mathrm{mg} / \mathrm{ml}$ (solution C) bovine albumin F-V was added. Solutions $\mathrm{B}$ and $\mathrm{D}$ were prepared by substituting $1 \mathrm{~mm} \mathrm{CaCl} \mathrm{m}_{2}$ and $1.5 \mathrm{mM} \mathrm{MgCl}_{2}$ for $2 \mathrm{~mm}$ EDTA in solutions $\mathrm{A}$ and $\mathrm{C}$, respectively. 
Cell Identification The identification of gastric ECL cells and mast cells were performed by acridine orange ${ }^{15)}$ and toluidine blue staining ${ }^{16)}$ respectively. In the present study, the ECL cells were stained by acridine orange $(10 \mu \mathrm{M})$, but not by toluidine blue $(1 \mathrm{~mm})$. Pentagastrin $(20 \mathrm{~nm})$ induced histamine release from the isolated rat gastric mucosal cells (vehicle: $0.01 \pm 0.01 \mu \mathrm{g} / 10^{5}$ cells, pentagastrin: $0.36 \pm 0.06$ $\mu \mathrm{g} / 10^{5}$ cells; $\left.p<0.01, n=4\right)$. On the other hand, isolated rat peritoneal mast cells were stained by toluidine blue $(1 \mathrm{~mm})$, but not by acridine orange $(10 \mu \mathrm{M})$. Pentagastrin $(20 \mathrm{nM}) \mathrm{did}$ not elicit the histamine release from the isolated mast cells (vehicle: $2.24 \pm 0.90 \mu \mathrm{g} / 10^{5}$ cells; pentagastrin: $2.26 \pm 1.22$ $\mu \mathrm{g} / 10^{5}$ cells, $\left.n=3\right)$.

Drugs Dibutyryl cyclic GMP, Percoll and pronase E were purchased from Sigma Chemicals (St. Louis, MO, U.S.A.). Bovine albumin was obtained from Nacalai Tesque (Kyoto, Japan). Sodium pentacyanonitrosylferrate(III) dihydrate (sodium nitroprusside) was purchased from Wako Pure Chemicals Industries (Osaka, Japan). ( \pm )-(E)-4-Methyl-2[ $(E)$-hydroxyimino]-5-nitro-6-methoxy-3-hexanamide (NOR 1) and 2-(4-carboxyphenyl)-4,4,5,5,-tetramethylimidazoline1-oxyl-3-amide, sodium salt (carboxy-PTIO) were obtained from Dojindo Laboratories (Kumamoto, Japan). 6-(Phenylamino)-5,8-quinolinedione (LY83583) was obtained from Sigma-Aldrich Co. (St. Louis, MO, U.S.A.). Sodium nitroprusside was dissolved in physiological saline, and dibutyryl cyclic GMP was dissolved in distilled water. LY83583 was dissolved in dimethylsulfoxide.

Statistics All data are indicated as the mean \pm S.E.M. Statistical analyses for percent data between two groups and among three or more groups were performed by Mann-Whitney $U$ test and by one-way analysis of variance (KruskalWallis test) followed by nonparametric Dunnett's multiple comparison test, respectively. A $p$ value $<0.05$ was considered statistically significant.

\section{RESULTS}

Effects of NO Donors and a Cyclic GMP Analogue on Histamine Release in Isolated Gastric Mucosal Cells As shown in Fig. 1, the addition of sodium nitroprusside augmented histamine release in a concentration-dependent manner $(3-10 \mu \mathrm{M})$. NOR 1 , another NO donor $(10-30 \mu \mathrm{M})$, also concentration-dependently increased histamine release (Fig. 1). The amount of histamine released by NOR 1 at $30 \mu \mathrm{M}\left(0.70 \pm 0.27 \mu \mathrm{g} / 10^{5}\right.$ cells $)$ attained more than two times the vehicle level $\left(0.30 \pm 0.08 \mu \mathrm{g} / 10^{5}\right.$ cells $)$, and was about $7 \%$ of that induced by pentagastrin at $20 \mathrm{~nm}$. Dibutyryl cyclic GMP $(20 \mu \mathrm{M})$ also promoted histamine release (Fig. 1).

As shown in Table 1, the trypan blue dye exclusion test was performed after incubating gastric mucosal cells with sodium nitroprusside and NOR 1 for $45 \mathrm{~min}$. The cell viabilities were not affected by incubation with the NO donors used.

Effects of Carboxy-PTIO and LY83583 on NOR 1-Induced Histamine Release in Isolated Gastric Mucosal Cells Histamine release augmented by NOR $1(30 \mu \mathrm{M})$ was inhibited by carboxy-PTIO $(500 \mu \mathrm{M})$, a NO scavenger $(p=$ 0.05 , compared with the NOR 1-treated group). Histamine release by NOR 1 was significantly inhibited by LY83583 $(30 \mu \mathrm{M})$, a soluble guanylate cyclase inhibitor (Fig. 2). These

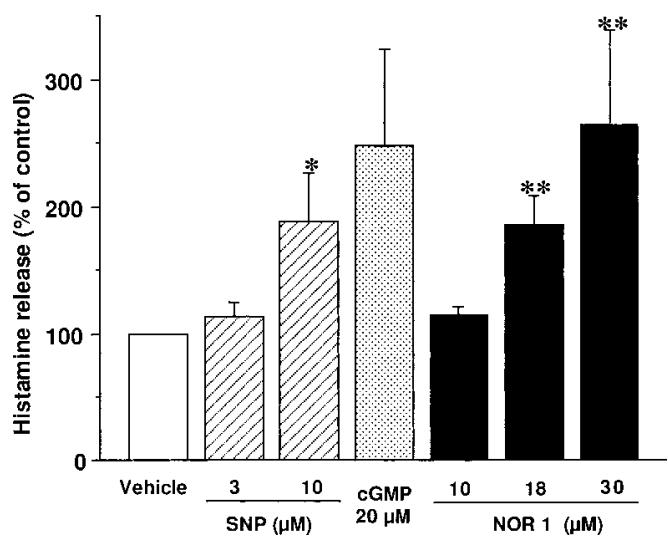

Fig. 1. Effects of Sodium Nitroprusside (SNP), Dibutyryl Cyclic GMP (cGMP) and NOR 1 on Histamine Release in Isolated Rat Gastric Mucosal Cells

Each value is expressed as a percentage of that of the control (vehicle-treated) group $\left(0.30 \pm 0.08 \mu \mathrm{g} / 10^{5}\right.$ cells histamine release). Each value represents the mean \pm S.E.M. of 3-6 experiments. Statistical analysis was performed by one-way analysis of variance (Kruskal-Wallis test) followed by nonparametric Dunnett's multiple comparison test. $* p<0.05, * * p<0.01$, significantly different from the control (vehicle-treated) group.

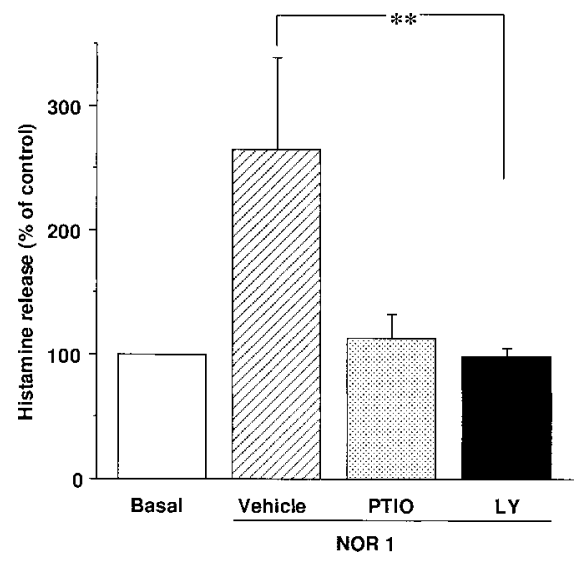

Fig. 2. Effects of Carboxy-PTIO (PTIO, $500 \mu \mathrm{M}$ ) and LY83583 (LY, $30 \mu \mathrm{M})$ on Histamine Release Induced by NOR $1(30 \mu \mathrm{M})$ in Isolated Rat Gastric Mucosal Cells

Each value is expressed as a percentage of that of the control (vehicle-treated) group $\left(0.30 \pm 0.08 \mu \mathrm{g} / 10^{5}\right.$ cells histamine release). Each value represents the mean \pm S.E.M. of $4-6$ experiments. Statistical analysis was performed by Mann-Whitney $U$ test. ** $p<0.01$, significantly different from the control (NOR 1 -treated) group.

Table 1. Viability of Isolated Rat Gastric Mucosal Cells after Treatment with NO Donors

\begin{tabular}{|c|c|c|c|c|c|}
\hline \multirow{2}{*}{ Vehicle } & \multicolumn{3}{|c|}{ NOR 1} & \multicolumn{2}{|c|}{ Sodium nitroprusside } \\
\hline & $10 \mu \mathrm{M}$ & $18 \mu \mathrm{M}$ & $30 \mu \mathrm{M}$ & $3 \mu \mathrm{M}$ & $10 \mu \mathrm{M}$ \\
\hline
\end{tabular}

$(\%)$

$98.7 \pm 1.1 \quad 98.6 \pm 1.1 \quad 99.2 \pm 0.6 \quad 97.5 \pm 1.0 \quad 97.9 \pm 1.1 \quad 98.8 \pm 1.2$

Percentages of trypan blue-negative cells after exposure to NO donors for $45 \mathrm{~min}$ are shown in the table. Each value represents the mean \pm S.E.M. of 4 experiments.

two agents reduced the histamine release by NOR 1 to the basal level. These results suggest that NO and cyclic GMP are involved in NOR 1-induction of histamine release.

\section{DISCUSSION}

There are two major types of histamine-containing cells in 
gastric mucosa: mucosal mast cell and ECL cell. ${ }^{9,10)}$ It is reported that depletion of ECL cell histamine decreases the gastrin-evoked acid response, ${ }^{17.18)}$ and that isolated mucosal mast cells do not respond to gastrin or carbachol. ${ }^{19)}$ Therefore, the gastric mucosal histamine-containing cells playing a role in acid secretion are supposed to be mainly ECL cells in rodents. In the present study, we also confirmed that pentagastrin elicits histamine release from isolated gastric mucosal cells, but did not from mast cells. Taken together, it is supposed that ECL cells in the isolated gastric mucosal cells are the origin of endogenous histamine relating to gastric acid secretion.

$S$-Nitroso- $N$-acetylpenicillamine, a NO donor, inhibited histamine-induced acid production in isolated rat parietal cells at higher doses $(100 \mu \mathrm{M}-1 \mathrm{~mm})$, suggesting its direct inhibitory action on parietal cells. ${ }^{2)}$ Kato et al. reported that intragastrically applied NO donors inhibited pentagastrininduced acid secretion and luminal release of histamine in anesthetized rats. ${ }^{5)}$ They suggest that the inhibition of acid secretion by NO donors results from a decrease in histamine release due to the inhibition of ECL cell function. Our previous study also showed that sodium nitroprusside at higher doses $(100 \mu \mathrm{M}-1 \mathrm{~mm})$ inhibited acid secretion induced by histamine, bethanechol and vagal stimulation in isolated mouse stomach. ${ }^{7)}$ Dibutyryl cyclic GMP at a higher dose (1 $\mathrm{mm})$ also reduced histamine-induced acid secretion in isolated mouse stomach. ${ }^{12)}$ Accordingly, the NO-cyclic GMP system plays an inhibitory role in peripheral control of acid secretion.

In contrast, we reported that augmented acid secretion was observed when sodium nitroprusside at a lower dose $(75 \mu \mathrm{M})$ was applied to isolated mouse stomach. ${ }^{7)}$ The acid secretion was almost completely inhibited by famotidine. Kawauchi et al. showed that the NO donor NOR-3 enhanced acid secretion via release of endogenous histamine in isolated bullfrog fundic mucosa preparations. ${ }^{20)}$ Dibutyryl cyclic GMP at a lower dose $(300 \mu \mathrm{M})$ also induced an increase of acid secretion that was abolished by famotidine in isolated mouse stomach, and an increase in histamine release in gastric mucosal cells. ${ }^{12)}$ In the present study, NO donors such as sodium nitroprusside and NOR 1 elicited the enhanced histamine release. We used the appropriate concentration of sodium nitroprusside $(3-10 \mu \mathrm{M})$, NOR $1(10-30 \mu \mathrm{M})$ and dibutyryl cyclic GMP $(20 \mu \mathrm{M})$ as the pharmacological tools, as reported previously. ${ }^{21-26)}$ Taken together, the NO-cyclic GMP system in gastric mucosal cells also plays a stimulatory role in peripheral control of acid secretion mediated by histamine under physiological conditions. This discrepancy between stimulation and inhibition of gastric acid secretion by NO may be explained by the working hypothesis that the concentration of NO determines whether NO stimulates or inhibits gastric acid secretion. It is assumed that a low concentration of NO has a stimulatory effect on gastric histamine-containing cells resulting in enhanced acid secretion, while a high concentration of NO has an inhibitory effect on parietal cells leading to inhibition of acid secretion.

In the present study, the NOR 1-induced histamine release was inhibited by LY-83583, a soluble guanylate cyclase inhibitor. In addition, the histamine release was markedly reduced by carboxy-PTIO, a NO scavenger. The concentrations of carboxy-PTIO and LY-83583 used in this study is the same as described in the other reports showing that these regents sufficiently induce pharmacological effects. ${ }^{27-30)}$ The present results suggest that exogenous NO promotes histamine release through an increase of cyclic GMP in histamine-containing cells.

Prinz et al. reported that production of NO by interleukin $1 \beta$ elicited histamine release from cultured ECL cells. ${ }^{31)}$ They speculate that the rise in histamine release is due to the cytotoxicity of NO. The present study showed that NO donors did not induce cell injury under our experimental conditions. Therefore, the histamine release by NO donors was not associated with gastric histamine-containing cells injury.

We already reported that $N$-nitro-L-arginine, a NO synthase inhibitor, markedly reduced acid secretion induced by a cholinergic agent, gastrin analogue or electrical vagus nerve stimulation in isolated mouse whole stomach. ${ }^{8)}$ Moreover, the increased histamine release in response to pentagastrin and bethanechol was also inhibited by $N$-nitro-L-arginine in isolated rat gastric mucosal cells. ${ }^{8)}$ Thus, endogenous NO enhances acid secretory response through histamine release. It is also reported that endogenous NO contributes to feedingand pentagastrin-induced acid secretion in in vivo experiments with $\operatorname{dogs}^{32}{ }^{32}$ and is involved in an increase of postprandial acid secretion in humans. ${ }^{33)}$ These reports support the hypothesis that NO stimulates gastric acid secretion under physiological conditions.

The mechanisms of endogenous NO-mediated histamine release in gastric mucosa have not yet been elucidated. Gastrin is known to elevate the activity of histidine decarboxylase, a histamine-forming enzyme, in gastric ECL cells. ${ }^{34,35)}$ It is reported that the NO-cyclic GMP pathway positively contributes to the activation of extracellular signal-regulated kinase, ${ }^{36)}$ and that extracellular signal-regulated kinase is essential for the gastrin effect on the activity of histidine decarboxylase. ${ }^{37)}$ Taking these reports into our consideration, endogenous NO may be involved in the histamine release from gastric ECL cells through the activation of extracellular signal-regulated kinase. In order to verify this point, we need further investigation.

The source of NO in gastric glands remains to be clarified. Constitutive NO synthase has been detected in gastric glandular mucosa. ${ }^{38,39)}$ Kitamura et al. propose vagal nerve as the origin. ${ }^{6)}$ It is likely that ECL cells or enteric nerve such as secretomotor neurons and intrinsic primary afferent sensory neurons $^{40)}$ contain constitutive NO synthase. Recently, Premaratne et al. demonstrated the expression of a neuronal isoform of NO synthase in rat parietal cells using immunohistchemical and molecular biological techniques. ${ }^{41)}$ They suggest the possibility that NO derived from parietal cells may act on adjacent endocrine cells such as ECL cells.

Studies on acid secretion always raise questions about a species difference. However, the above reports describe increased acid secretion via NO in several species. We demonstrated that endogenous and exogenous NO induces gastric acid secretion via histamine release in isolated mouse stomach. ${ }^{7,8)}$ The results from the present study in isolated rat gastric mucosal cells supported this hypothesis. Therefore, the species difference is thought not to be very important for the present results. The secretory responses stimulated by the NO-cyclic GMP mechanism have been reported in other se- 
cretory cell systems. ${ }^{4-44)}$

In conclusion, we demonstrated that $\mathrm{NO}$ donors enhanced histamine release from gastric histamine-containing cells, possibly ECL cells. This histamine release results from intracellular cyclic GMP increased by NO, which stimulates gastric acid secretion. It is likely that NO functions as a mediator responsible for stimulation of gastric acid secretion.

Acknowledgments This study was supported in part by Grants-in-Aid for Scientific Research from the Ministry of Education, Culture, Sports, Science and Technology, Japan. The authors express our gratitude to Dr. Toshihiko Murayama, Graduate School of Pharmaceutical Sciences, Chiba University, for instructive advice on this manuscript.

\section{REFERENCES AND NOTES}

1) Present address: Toray Industries, Inc. Pharmaceutical research laboratories, Kanagawa 248-8555, Japan.

2) Brown J. F., Hanson P. J., Whittle B. J. R., Biochem. Biophys. Res. Commun., 195, 1354-1359 (1993).

3) Barrachina D., Calatayud S., Esplugues J., Whittle B. J. R, Moncada S., Esplugues J. V., Eur. J. Pharmacol., 262, 181-183 (1994).

4) Kim H., Kim K. H., Pharmacology, 53, 331-339 (1996).

5) Kato S., Kitamura M., Korolkiewic R. P., Takeuchi K., Br. J. Pharmacol., 123, 839-846 (1998).

6) Kitamura M., Sugamoto S., Kawauchi S., Kato S., Takeuchi K., J. Pharmacol. Exp. Ther, 291, 181-187 (1999).

7) Hasebe K., Horie S., Yano S., Watanabe K., Eur. J. Pharmacol., 420, 159-164 (2001)

8) Hasebe K., Horie S., Yano S., Watanabe K., Eur. J. Pharmacol., 350, 229-236 (1998).

9) Soll A. H., Toomey M., Culp D., Shanahan F., Beaven M. A., Am. J. Physiol., 254, G40-G48 (1988).

10) Håkanson R., Böttcher G., Ekblad E., Panula P., Simonsson M., Dohlsten M., Hallberg T., Sundler F., Histochemistry, 86, 5-17 (1986).

11) Hersey S. J., Sachs G., Pharmacol. Rev., 75, 155-189 (1995).

12) Horie S., Hasebe K., Koshikawa H., Tsuchiya S., Yano S., Watanabe K., J. Physiol. (Paris), 94, 25-29 (2000).

13) Schepp W., Kath D., Tatge C., Zimmerhackl B., Scusdziarra V., Classen M., Gastroenterology, 97, 1420-1429 (1989).

14) Sakai H., Tabuchi Y., Kakinoki B., Seike H., Kumagai S., Matsumoto C., Takeguchi N., Eur. J. Pharmacol., 291, 153-158 (1995).

15) Prinz C., Kajimura M., Scott D. R., Mercier F., Helander H. F., Sachs G., Gastroenterology, 105, 449_461 (1993).

16) Brenna E., Waldum H. L., Scand. J. Gastroenterol., 26, 1295-1306 (1991).

17) Andersson K., Cabero J. L., Mattsson H., Håkanson R., Scand. J. Gastroenterol., 31, 24-30 (1996).
18) Chen D., Monstein H., Nylander A., Zhao C., Sundler F., Håkanson R., Regul. Gastroenterol., 107, 18-27 (1994).

19) Rangachari P. K., Am. J. Physiol., 262, G1-G13 (1992).

20) Kawauchi S., Sugamoto S., Furukawa O., Mimaki H., Takeuchi K., J. Physiol. Pharmacol., 52, 93-105 (2001).

21) Petkov G. V., Spassov G. D., Boev K. K., Eur. J. Pharmacol., 354, 59-66 (1998).

22) Kiviluoto T., Watanabe S., Hirose M., Sato N., Mustonen H., Puolakkainen P., Rönty M., Ranta-Knuuttila T., Kivilaakso E., Am. J. Physiol. Gastrointest. Liver Physiol., 281, G1151-G1157 (2001).

23) Takeuchi T., Sugimoto K., Morimoto H., Fujita A., Hata F., Jpn. J. Pharmacol., 86, 390-398 (2001).

24) Sato M., Kawatani M., Neurosci. Lett., 206, 69-72 (1996).

25) Sakai H., Ikari A., Shimizu T., Sato T., Takeguchi N., Eur. J. Pharmacol., 361, 109-117 (1998).

26) Sistiaga A., Miras-Portugal M. T., Sanchez-Prieto J., Eur. J. Pharmacol., 321, 247-257 (1997).

27) Rand M. J., Li C. G., Br. J. Pharmacol., 116, 1906-1910 (1995).

28) Philip M., Mark R. C., Calum J. M., Denice F., Pamela J. S., Brain Res., 911, 203-210 (2001).

29) Rebuffat P., Malendowicz L. K., Nussdorfer G. G., Mazzocchi G., Peptides, 22, 923-926 (2001).

30) Schmidt M. J., Sawyer B. D., Truex L. L., Marshall W. S., Fleisch J. H., J. Pharmacol. Exp. Ther, 232, $764-769$ (1985).

31) Prinz C., Neumayer N., Mahr S., Classen M., Schepp W., Gastroenterology, 112, 363-375 (1997).

32) Bilski J., Konturek S. J., Cieszkowski M., Czarnobilski K., Pawlik W. W., Biomed. Res., 15 (Suppl. 2), 63-67 (1994).

33) Konturek J., Fischer H., Gromotka P. M., Konturek S. J., Domschke W., Aliment. Pharmacol. Ther., 13, 1683-1691 (1999).

34) Chen D., Zhao C. M., Yamada H., Norlen P., Håkanson R., Regul. Pept., 77, 169-175 (1998).

35) Prinz C., Scott D. R., Hurwitz D., Helander H. F., Sachs G., Am. J. Physiol., 267, G663 - G675 (1994).

36) Gu M., Lynch J., Brecher P., J. Auton. Nerv. Syst., 81, 87-96 (2000).

37) Höcker M., Henihan R. J., Rosewicz S., Riecken E., Zhang Z., Koh T. J., Wang T. C., J. Biol. Chem., 272, 27015-27024 (1997).

38) Price K. J., Hanson P. J., Whittle B. J. R., Cell Tissue Res., 285, 157163 (1996).

39) Byrne C. R., Price K. J., Williams J. M., Brown J. F., Hanson P. J., Whittle B. J. R., Biochim. Biophys. Acta, 1356, 131-139 (1997).

40) Furness J. B., J. Auton. Nerv. Syst., 81, 87-96 (2000).

41) Premaratne S., Xue C., McCarty J. M., Zaki M., McCuen R. W., Johns R. A., Schepp W., Neu B., Lippman R., Melone P. D., Schubert M. L., Am. J. Physiol. Gastrointest. Liver Physiol., 280, G308-G313 (2001).

42) Nguyen B. L., Saitoh M., Ware J. A., Am. J. Physiol., 261, H1043H1052 (1991).

43) Florucci S., Distrutti E., Chiorean M., Santucci L., Belia S., Fano G., Giorgio R., Stanghellini V., Corinaldesi R., Morelli A., Gastroenterology, 109, 1214-1223 (1995).

44) Okayama N., Itoh M., Joh T., Miyamoto T., Takeuchi T., Moriyama A., Kato T., Biochim. Biophys. Acta, 1268, 185-190 (1995). 